\title{
PEMANFAATAN DAN EFISIENSI KURKUMIN KUNYIT (CURCUMA DOMESTICA VAL) SEBAGAI INDIKATOR TITRASI ASAM BASA
}

\author{
Ratna Sundari \\ Magister Teknik Industri, Fakultas Teknologi Industri, Universitas Islam Indonesia, \\ Jl. Kaliurang Km. 14,5, Sleman, Yogyakarta, 55584 \\ E-Mail:ratna_sundari@politeknik-lpp.ac.id
}

\begin{abstract}
The composition of the turmeric plant consists of a root, rhizome, pseudostem, stem leaf, leaves, flower stalks and flowers. Chemical substances contained in turmeric is essential oil, starch, fiber and ash. Turmeric chemical content will be higher if it comes from the lowland compared with turmeric, which comes from the highlands. Curcumin is coloring agentto orange yellow crystalline, insoluble in ether, soluble in oils, alkali maroon, while the bright yellow acid. $\mathrm{pH}$ indicator is an organic acid or base having one color if the hydrogen concentration is higher than at a certain price and a color if the concentration was lower. The analysis shows that the optimum extraction temperature is $70{ }^{\circ} \mathrm{C}$, with the extraction time of 120 minutes, the particle size of 100 mesh.Concentration yield is curcumin produced $5.158 \mathrm{mg} / \mathrm{L}$. The cost efficiency of the use of curcumin indicator reached $27,7 \%$.
\end{abstract}

Keywords : Extraction, Indicators, Acids, Bases, Curcumin.

\section{PENDAHULUAN}

Dalam perdagangan internasional kunyit termasuk salah satu komoditas eksport. Kebutuhan kunyit untuk seluruh dunia diperkirakan 12.000 ton per tahun. Di Eropa rimpang kunyit digunakan untuk pewarna makanan berbagai jenis makanan diantaranya keju, mentega dan mustard. Bagian dari kunyit yang paling banyak digunakan adalah bagian rimpang yang dimanfaatkan untuk ramuan obat tradisional, bahan pewarna tekstil dan makanan serta bumbu masakan, rempah-rempah dan bahan kosmetik.

Kunyit termasuk tanaman tahunan yang tumbuhnya merumpun. Susunan dari tanaman kunyit terdiri dari akar, rimpang, batang semu, pelepah daun, daun, tangkai bunga dan kuntum bunga. Rimpang kunyit tumbuh dari umbi utama, yang bentunya bervariasi antara bulat-panjang, pendek dan tebal lurus ataupun melengkung. Batang tanaman kunyit relatif pendek membentuk tanaman semu dari pelepah daun yang saling menutupi.
Kandungan zat kimia yang terdapat dalam rimpang kunyit adalah minyak atsiri, pati, serat dan abu. Rimpang kunyit kandungan kimianya akan lebih tinggi apabila berasal dari dataran rendah dibandingkan dengan kunyit yang berasal dari dataran tinggi. Seperti pada tabel 1 berikut.

Komponen utama dalam rimpang kunyit adalah kurkuminoid dan minyak atsiri. Berdasarkan hasil penelitian Balai Penelitian Tanaman Rempah dan Obat (Balittro) bahwa kandungan kurkumin rimpang kunyit ratarata $10,92 \%$.

Zat warna kurkumin menurut (Nugroho, 1998) adalah kristal berwarna kuning orange, tidak larut dalam ether, larut dalam minyak, dalam alkali berwarna merah kecoklatan, sedangkan dalam asam berwarna kuning muda. Kurkumin memberikan perubahan warna yang jelas dan cepat yaitu kurang dari 5 detik sehingga dimungkinkan sebagai indikator (Muhammad R, 2007). 
Tabel 1. Kandung Kimia Pada Rimpang Kunyit

\begin{tabular}{|c|c|c|}
\hline Kandungan zat (bobot kering) & Dataran rendah $(240 \mathrm{dpl})$ & Dataran tinggi $(1200 \mathrm{dpl})$ \\
\hline Kadar minyak atsiri (\%) & 1,8100 & 1,4600 \\
\hline Kadar pati $(\%)$ & 55,030 & 47,8100 \\
\hline Kadar serat (\%) & 3,4400 & 2,8700 \\
\hline Kadar abu (\%) & 6,4700 & 7,5200 \\
\hline Indek bias & 1,5030 & 1,5086 \\
\hline Bobot jenis & 0,9300 & 0,9465 \\
\hline Warna minyak & Kuning & Kuning \\
\hline
\end{tabular}

Indikator asam basa adalah asam atau basa organik yang mempunyai satu warna jika konsentrasi hidrogen lebih tinggi dari pada suatu harga tertentu dan suatu warna lain jika konsentrasi itu lebih rendah. Indikator asam basa dapat berubah warna apabila $\mathrm{pH}$ lingkungan berubah. Apabila dalam suatu titrasi asam maupun basa merupakan elektrolit kuat, larutan pada titik ekuivalen akan mempunyai $\mathrm{pH}=7$. Apabila asam ataupun basa merupakan elektrolit lemah, garam yang terjadi akan mengalami hidrolisis pada titik ekivalen larutan akan mempunyai $\mathrm{pH}>7$. Harga $\mathrm{pH}$ yang tepat dapat dihitung dari tetapan ionisasi dari asam atau basa lemah tersebut dan dari konsentrasi larutan yang diperoleh.

Titrasi asam basa (Keenan,1984) adalah proses penentuan banyaknya larutan dengan konsentrasi yang diketahui dan diperlukan untuk bereaksi secara lengkap dengan sejumlah contoh tertentu yang akan dianalisis. Prosedur analitis yang melibatkan titrasi dengan larutan - larutan yang konsentrasinya diketahui disebut titrasi volumetri. Dalam titrasi asam basa, titrasi melibatkan pengukuran yang seksama volume - volume suatu asam dan suastu basa yang tepat saling menetralkan. Titik akhir titrasi adalah titik dimana indikator berubah warna, dengan memilih indikator secara seksama, titik akhir itu akan tepat berimpit dengan titik kesetaraan.
Adanya kandungan kurkumin pada kunyit dapat ditunjukkan dengan titrasi basa kuat dan asam kuat dan titrasi asam lemah dengan asam kuat. Disamping itu digunakan juga indikator fenolftalein (PP) dan methyl orange (mo).

\section{METODE PENELITIAN \\ 2.1. Bahan \\ 1) Kunyit. \\ 2) Ethanol $96 \%$.}

\subsection{Alat}

1) Rangkaian alat ekstraksi.

2) Rangkaian alat distilasi.

3) Oven.

4) Thin Layer Chromathografi (TLC).

\subsection{Cara Kerja}

Kunyit dikupas, cuci bersih dan jemur sampai kering. Hancurkan kunyit dalam beberapa ukuran. Ekstraksi bubuk kunyit dengan labu leher tiga dalam waktu yang ditentukan. Distilasi larutan untuk menguapkan etanolnya sampai tidak ada yang menetes lagi. Residu yang dihasilkan kemudian didinginkan dan disaring. Kristal dioven sampai dengan berat konstan, kemudian dicek kadarnya menggunakan TLC. Kristal kurkumin kemudian dilarutkan dalam alkohol dan siap digunakan untuk indikator titrasi asam basa. 
Tabel 2. Pengaruh Waktu Ekstraksi dan Berat Kurkumin.

\begin{tabular}{c|c}
\hline Waktu Ekstraksi (Menit) & Berat Kurkumin (gr) \\
\hline 20 & 2,75 \\
40 & 3,2 \\
60 & 3,5 \\
80 & 3,6 \\
100 & 4 \\
120 & 4,2 \\
140 & 4 \\
160 & 3,9 \\
\hline
\end{tabular}

Tabel 3. Pengaruh Suhu Ekstraksi dengan Berat Kurkumin

\begin{tabular}{c|c}
\hline Suhu Ekstraksi $\left({ }^{\mathbf{0}} \mathbf{C}\right)$ & Berat Kurkumin (gr) \\
\hline 10 & - \\
20 & - \\
30 & 4,1 \\
40 & 4,5 \\
50 & 5 \\
60 & 5,8 \\
70 & 6 \\
80 & 3,2 \\
\hline
\end{tabular}

\section{Hubungan Antara Waktu \\ Ekstraksi dan Berat Kurkumim (gr)}

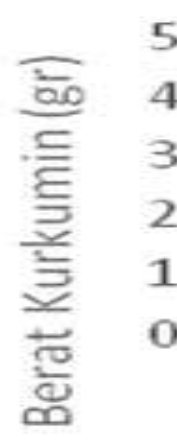

\section{$20 \quad 40 \quad 60 \quad 80 \quad 100 \quad 120 \quad 140 \quad 160$ Waktuekstraksi (menit)}

Gambar 1. Grafik Waktu Ekstraksi dan Berat Kurkumim. 


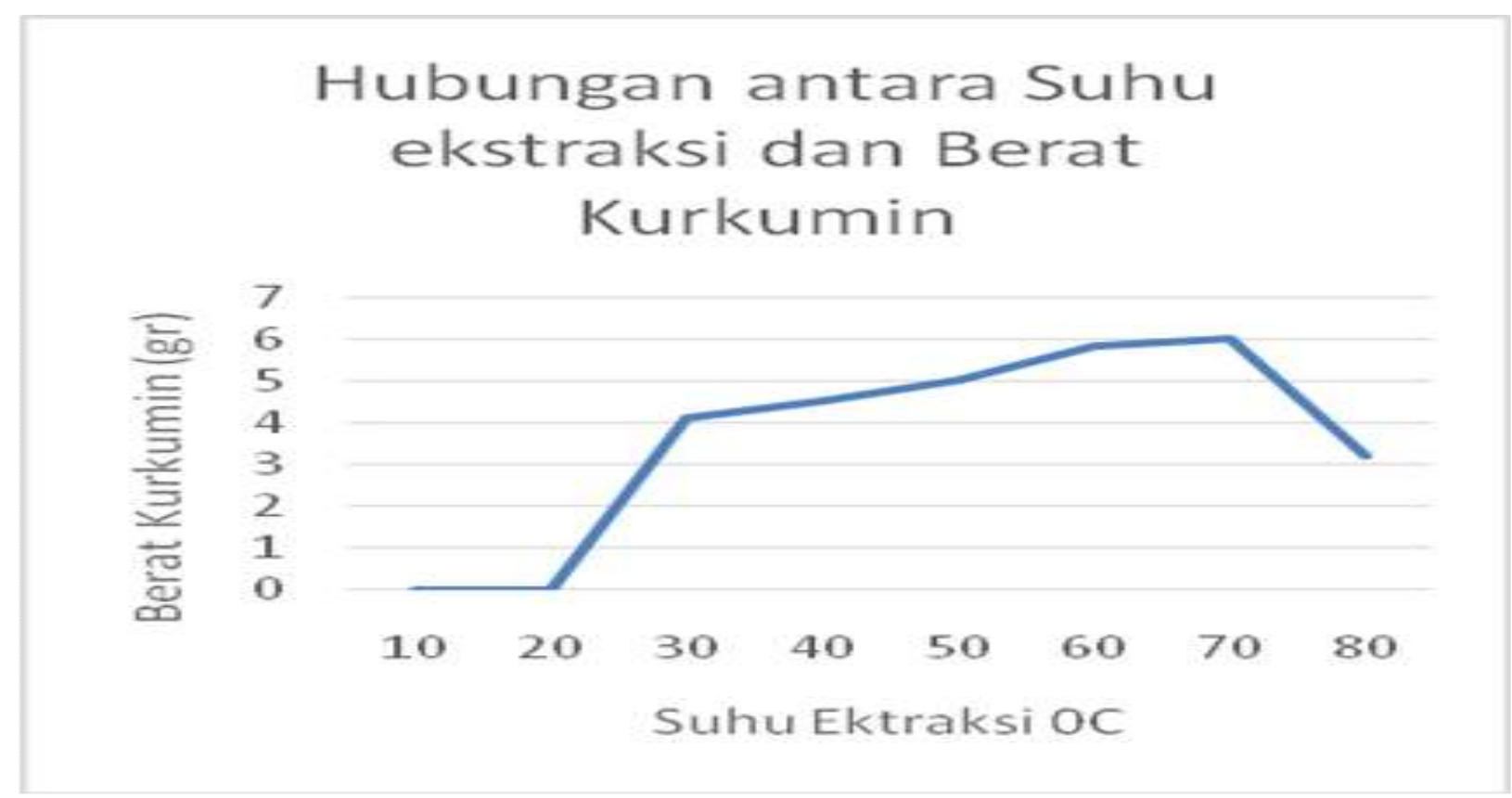

Gambar 2. Grafik Suhu Ekstraksi dan Berat Kurkumim.

\section{HASIL DAN PEMBAHASAN}

Variasi yang dilakukan dalam penelitian adalah pengaruh waktu ekstraksi, suhu ekstraksi dan ukuran butir kristal kurkumin.

\subsection{Pengaruh Waktu Ekstraksi}

Hasil dari penelitian pengaruh waktu ekstraksi dapat diperoleh seperti tabel 2 diatas. Dari tabel diperoleh hasil bahwa semakin lama waktu ekstraksi berat kurkumin akan semakin meningkat dan berat yang optimal diperoleh pada ekstraksi selama 120 menit, apabila waktu diperpanjang lagi sudah tidak efektif lagi karena waktu kontak yang diperlukan pelarut dengan bahan kunyit sudah mencapai kesetimbangan sehingga berat kurkumin mengalami penurunan.

\subsection{Pengaruh Suhu Ekstraksi}

Hasil dari penelitian pengaruh suhu ekstraksi diperoleh hasil seperti tabel 3 diatas. Dari hasil dapat diketahui bahwa semakin tinggi suhu ekstraksi berat kurkumin akan semakin bertambah dengan waktu ekstraksi yang sama.

Suhu yang optimal dalam ekstraksi adalah pada suhu $70{ }^{0} \mathrm{C}$ apabila dipanaskan lagi akan terjadi penurunan jumlah kurkumin. Hal ini terjadi karena titik didih etanol $78,4{ }^{\circ} \mathrm{C}$, sehingga pada suhu ektraksi diatas titik didih tersebut sebagian besar ethanol akan menguap. Sehingga daya larut sudah tidak efektif lagi apabila suhu diatas titik didih etanol.

Dari tabel diatas dapat diketahui bahwa semakin kecil ukuran serbuk kunyit maka hasil kurkumin juga akan semakin banyak. Hal tersebut disebabkan karena semakin kecil ukuran butir akan semakin mudah pelarut melarutkan minyak atsiri, beserta zat warna, resin dan zat lain seperti protein dan waxe yang terkandung dalam serbuk kunyit.

Dari berbagai variasi percobaan diperoleh hasil yang optimal dengan 50 gr serbuk kunyit ukuran partikel 100 mesh setara dengan $0,841 \mathrm{~mm}$ dengan $200 \mathrm{ml}$ etanol diekstraksi pada suhu $70^{\circ} \mathrm{C}$ selama 120 menit. Kurkumin yang diperoleh sebanyak 6,519 gr. Hasil kurkumin dianalisa dengan TLC Scanner menghasilkan kadar 5,158 $\mathrm{mg} / \mathrm{ml}$. Penentuan jumlah penggunaan larutan kurkumin sebagai indikator untuk menentukan kadar kurkumin yang tepat sebagai indikator dilakukan dengan mencampurkan kurkumin dengan kadar $5,158 \mathrm{gr} / \mathrm{mL}$ dengan alkohol berbagai macam variasi yaitu $1 \%, 3 \%$ dan $5 \%$. Dengan melihat perubahan warna pada titik akhir titrasi yaitu merah muda. 
Tabel 4. Pengaruh Ukuran Partikel dengan Berat Kurkumin

\begin{tabular}{c|c}
\hline Berat kurkumin (gr) & Ukuran Partikel (mm) \\
\hline 5,6 & 0,841 \\
5,85 & 0,400 \\
6 & 0,250 \\
6,4 & 0,177 \\
6,5 & 0,149 \\
\hline
\end{tabular}

Tabel 5. Penggunaan Indikator Kurkumin Pada Tirasi 0,1M HCl dengan 0,1M NaOH

\begin{tabular}{c|c|c|c|c}
\hline $\begin{array}{c}\text { Larutan Kurkumin } \\
(\% \text { vol) }\end{array}$ & \multicolumn{4}{|c}{ Jumlah penggunaan Indikator Kurkumin } \\
\hline & 1 tetes & 2 tetes & 3 tetes & 4 tetes \\
\hline 1 & - & - & - & - \\
5 & - & - & - & $* * *$ \\
\hline
\end{tabular}

\subsection{Pengaruh Ukuran Partikel}

Hasil dari pengaruh ukuran partikel terhadap berat kristal kurkumin diperoleh data pada tabel 4 diatas.

Dari tabel di atas dapat dibuktikan bahwa larutan kurkumin 5\% sebanyak 4 tetes dapat memberikan perubahan warna yang jelas dan secara mendadak pada titrasi $10 \mathrm{ml}$ HCL $0,1 \mathrm{M}$ yang dititrasi dengan $\mathrm{NaOH}$ 0,1M. Sehingga indikator kurkumin yang tepat untuk dipakai adalah 5\%.

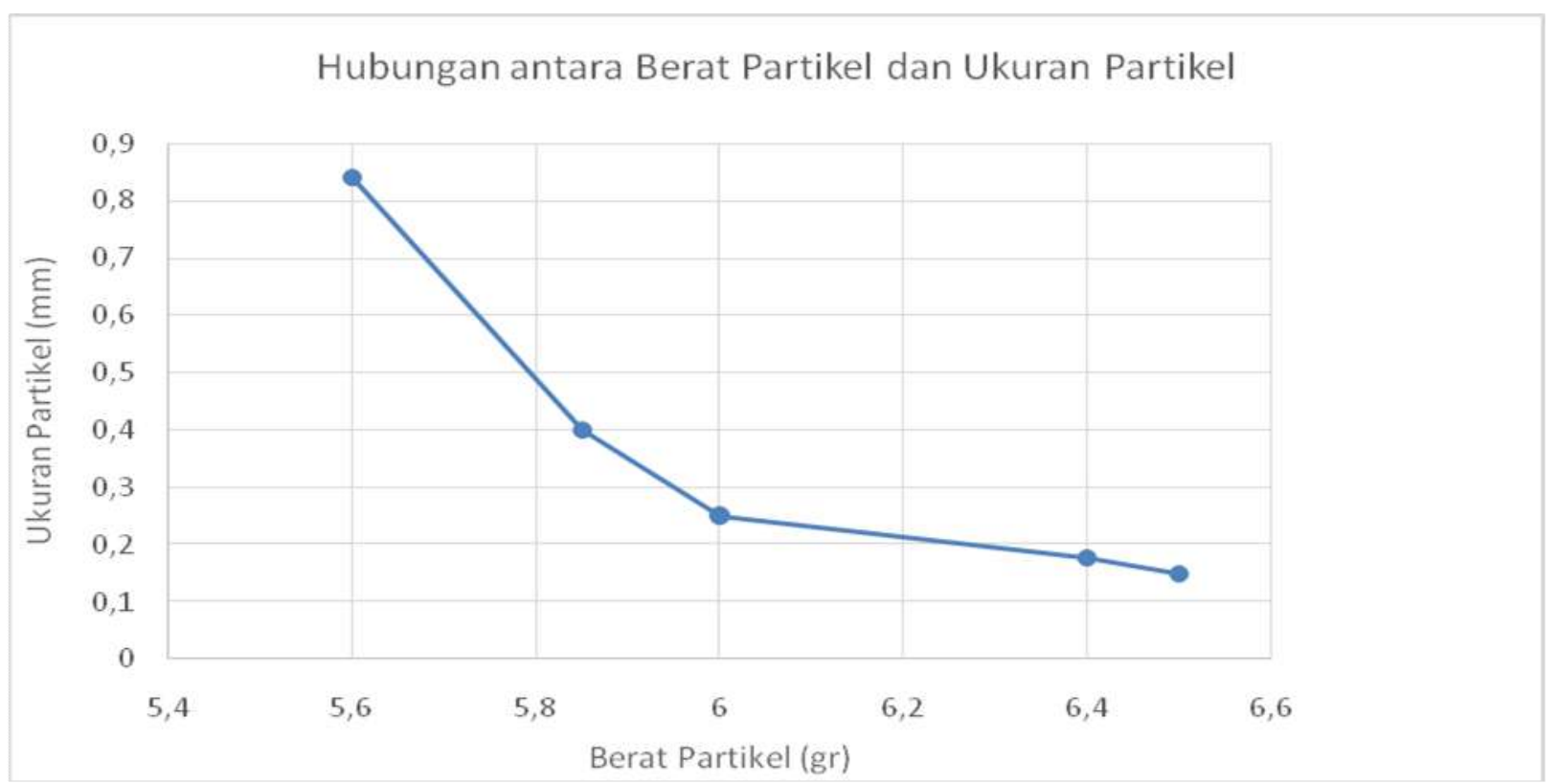

Gambar 3. Grafik Berat Partikel dan Ukuran Partikel. 


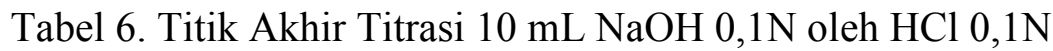

\begin{tabular}{c|c|c}
\hline \multirow{2}{*}{ No } & \multicolumn{2}{|c}{ Volume HCI $(\mathbf{m L})$} \\
\cline { 2 - 3 } & Indikator pp & Indikator Kurkumin \\
\hline 1 & 9,50 & 9,55 \\
2 & 9,50 & 9,55 \\
3 & 9,50 & 9,60 \\
4 & 9,50 & 9,55 \\
5 & 9,50 & 9,56 \\
\hline Rerata & $\mathbf{9 , 5 0}$ & $\mathbf{9 , 5 6}$ \\
\hline
\end{tabular}

Tabel 7. Titik Akhir Titrasi 10mL NH4OH Dengan HCl 0,1N

\begin{tabular}{c|c|c}
\hline \multirow{2}{*}{ No } & \multicolumn{2}{|c}{ Volume HCl $(\mathbf{m L})$} \\
\cline { 2 - 3 } & Indikator mo & Indikator kurkumin \\
\hline 1 & 10,73 & 10,71 \\
2 & 10,73 & 10,71 \\
3 & 10,73 & 10,71 \\
4 & 10,73 & 10,71 \\
5 & 10,73 & 10,71 \\
\hline Rerata & $\mathbf{1 0 , 7 3}$ & $\mathbf{1 0 , 7 1}$ \\
\hline
\end{tabular}

3.3.1.Perbandingan Titrasi $\mathrm{NaOH}$ oleh $\mathrm{HCl}$ dengan Indikator Kurkumin dan PP

Dengan menggunakan indikator Kurkumin dan PP dalam titrasi $10 \mathrm{ml} \mathrm{NaOH}$ $0,1 \mathrm{~N}$ oleh $\mathrm{HCl} 0,1 \mathrm{~N}$ dapat diperoleh data titrasi pada tabel 6 diatas. Dari hasil analisa diperoleh penyimpangan sebesar $0,63 \%$ yaitu perbedaan titik akhir pada titrasi dengan indikator pp dan kurkumin sangat kecil, sehingga kurkumin layak digunakan sebagai alternatif indikator pp (fenolftalein) dalam titrasi asam basa. $\mathrm{pH}$ akhir dari titrasi dengan kurkumin di peroleh hasil $\mathrm{pH}$ 8,6989, sedangkan dengan indikator pp diperoleh $\mathrm{pH}$ akhir 9,0015.

\subsubsection{Perbandingan Titrasi NH4OH oleh} HCl dengan menggunakan indikator kurkumin dan mo (methyl orange)

Penentuan titik akhir titrasi $10 \mathrm{~mL}$ $\mathrm{NH} 4 \mathrm{OH} \quad 0,1 \mathrm{~N}$ oleh $\mathrm{HCl} 0,1 \mathrm{~N}$ dengan indikator mo dengan pembanding indikator kurkumin dapat dilihat dalam tabel 7 diatas. Dari hasil penelitian diperoleh hasil penyimpangan $0,18 \%$ ditunjukkan oleh indikator kurkumin.
Sehingga indikator kurkumin dapat digunakan sebagai indikator alternatif pengganti methyl orange (mo) untuk titrasi asam basa. pH akhir dari titrasi menggunakan indikator mo 4,2668 sedangkan untuk titrasi menggunakan kurkumin diperoleh pH akhir 5,8568.

\subsubsection{Efisiensi Biaya Penggunaan Indikator Kurkumin}

- Harga indikator pp Rp. 13.500,-/10 ml, Rp. $270.000 / 200 \mathrm{ml}$.

- Harga indikator mo Rp. 13.500,./10 ml, Rp. $270.000 / 200 \mathrm{ml}$.

- Biaya pembuatan $200 \mathrm{ml}$ indikator kurkumin Rp. 195.000,-.

Selisih harga beli indikator pp dan mo dengan membuat sendiri $=$ Rp. $270.000-$ 195.000,- $=$ Rp.75.000,-. Perhitungan efisiensi biaya dengan menggunakan pendekatan rumus Rasio Efisiensi.

Rasio Efisiensi $=\frac{\mathrm{A}-\mathrm{R}}{\mathrm{A}} \times 100 \%$

dengan :

$\mathrm{A}=$ Harga Beli.

$\mathrm{R}=$ Harga Produksi. 
Efisiensi biaya pembuatan indikator kurkumin untuk pengganti pp dan mo :

Ras.o Efisiensi $=\frac{270.000-195.000}{270.000} \times 100 \%=27,7 \%$

\section{KESIMPULAN}

Hasil dari penelitian diatas dapat disimpulkan sebagai berikut :

1. Ekstraksi kurkumin merupakan cara yang sederhana dalam pengambilan kurkumin pada kunyit.

2. Ekstraksi yang optimum dilakukan pada suhu $70{ }^{0} \mathrm{C}$ dalam waktu 120 menit, dengan ukuran partikel 100 mesh setara dengan $0,841 \mathrm{~mm}$ sehingga kurkumin yang dihasilkan sebanyak 6,519 gram mengandung kadar 5,158 gr/mL.

3. Kurkumin dapat digunakan sebagai alternatif pengganti indikator fenolftalein dan methyl orange.

4. Kurkumin dapat digunakan sebagai indikator dengan pengenceran sebanyak $5 \%$ volume sebanyak 4 tetes.

5. Efisiensi biaya penggunaan indikator $\mathrm{pp}$ dan mo sebanyak $90,74 \%$.

\section{DAFTAR PUSTAKA}

Fachry,A.R., Fenilla B,. Farhan M. Ekstraksi Senyawa Kurkumin dari Kunyit (Curcuma Longa Linn) Sebagai Zat Pewarna Kuning pada Proses Pembuatan Cat. Jurnal Teknik Kimia. No.3 Vol 19, 2014.

Harjanti,R.S., Pemungutan Kurkumin dari Kunyit (Curcuma domestica val.) dan Pemakaiannya Sebagai Indikator Analisis Volumetri. Jurnal Rekayasa Proses, Vol.2, No.2, 2008.

Keenan, Kleinfelter, Wood, Pudjaatmaka, A.H. Kimia Untuk Universitas. Erlangga. Jakarta, 1980.

Mohammad, R., Ahmad, M., Daud,J.M,. Potensi Kurkumin Sebagai Penunjuk pH Semula Jadi Untuk Pembangunan Sensor Optik pH, M.J.A.S II, 2007.

Nugroho N.A. Manfaat dan Prospek Pengembangan Kunyit. Trubus Agriwidya. Ungaran, 1998.

Rukmana,R. Kunyit. Kanisius. Yogyakarta, 1995. 